\title{
下肢深部静脈血栓症にみられる血液凝固異常の検討 一とくに再発例との関連について一
}

\author{
矢 尾 善 英*, 石 丸 新*
}

\begin{abstract}
下肢深部静脈血栓症の再発と血液凝固異常症との関連性を中心に検討した。258例を対象に再発の 有無について平均 34 力月間観察した。これらのうち 98 例について治療開始前に血液凝固異常症のス クリーニング検查を行ったところ，8例 (8\%) にその合併がみられた（AT-III 欠乏症 3 例，プロティ ン C 欠乏症 3 例, プロテイン $\mathrm{S}$ 欠乏症 1 例, 抗リン脂質抗体症候群 1 例)。また慢性期に下肢深部静脈 血栓症が再発した症例は 258 例中 12 例 (5\%) あり，このうち血液凝固異常症合併例は 5 例 $(42 \%)$ で あり, 再発例では血液疑固異常症の合併が高率であった．慢性期の薬物療法としては全例にワーファ リンを投与し, 127 例には抗血小板剤を併用した。この投与期間に関しては再発例と非再発例で差はな かった。再発時期はワーファリン投与中止後 1 カ月から 36 カ月の間であった。 以上の結果より, 血液 凝固異常症を合併している症例では，再発予防の目的で長期間のワーファリン投与を行う必要がある と考えられる。
\end{abstract}

Key words : deep vein thrombosis, reccurent deep vein thrombosis, thrombophilia, warfarin, antiplatelet drug

\section{緒 言}

深部静脈血栓症の原因として血液凝固異常症 の関与が注目されている。しかし，血液凝固異 常症を合併した深部静脈血栓症の慢性期におけ る抗凝固療法の継続期間や中止後の再発に関し ては未だ不明な点が多い。そこで，今回は深部 静脈血栓症の慢性期における再発と血液凝固異 常症との関連性について検討した。

\section{対象, 方法}

1986 年 4 月から 1997 年 8 月までに発症 2 週 間以内に当科を受診した急性下肢深部静脈血栓 症患者 258 例を対象とした。年齢は 5〜81 歳 (平 均 55.5 歳), 男女比は $127: 131$ であった. 深部
静脈血栓症の診断は全例, 下肢静脈造影にて行 った。観察期間は 4 力月〜 115 力月（平均 34 力 月）であった（Table. 1).

このうち再発例は 12 例あり,その初発時の年 齢は 20〜 57 歳 (平均 44.5 歳) で, 男女比は 3 : 9 であった。

Table 1 Patients

\begin{tabular}{|c|c|c|c|c|}
\hline & total & non-recurrence & recurrence \\
\hline \multicolumn{2}{|l|}{ No. } & 258 & 246 & 12 \\
\hline \multicolumn{2}{|c|}{$\begin{array}{l}\text { Mean age (yr) } \\
\text { at first episode }\end{array}$} & 55.5 & $56.0^{*}$ & $44.5^{*}$ \\
\hline \multirow[t]{2}{*}{ Sex } & male & 127 & 124 & 3 \\
\hline & female & 131 & 122 & 9 \\
\hline \multirow[t]{2}{*}{ Region } & left & 183 & 174 & 9 \\
\hline & right & 75 & 72 & 3 \\
\hline \multicolumn{2}{|c|}{ Operation } & 12 & 12 & 0 \\
\hline
\end{tabular}

* $: \mathrm{P}<0.05$

* 東京医科大学外科第二講座 〔 $\overline{\mathrm{T}} 163-0023$ 東京都新宿区西新宿 6-7-1)

Department of surgery II, Tokyo Medical College [6-7-1 Nishishinjuku, Shinju-ku, Tokyo 160-0023, Japan.]

受付 : 1998. 2. 18, 受理 : 1998. 3. 23 . 
これらのうち, 再発例 12 例を含めた 98 例に ついて治療開始前に血液凝固異常症のスクリー ニング検査を行った。スクリーニング検査項目 としてフィブリノーゲン（測定法：トロンビン 時間法，正常範囲: $200 \sim 400 \mathrm{mg} / \mathrm{d} l$, 以下同 じ), アンチトロンビン III 活性（合成基質法, 80 120\%)，プラスミノーゲン活性（合成基質 法，80 120\%)，プロテインC 活性(APTT 凝 固時間法，55～140\%)，プロテイン $\mathrm{S}$ 活性 (APTT 凝固時間法, 60\% 150\%)，ループスア ンチコアグラント (希釈プロトロンビン法, 4.10 末満), 活性化プロテインCレジスタンス (Activated proteinC resistance, APCR)（重複 法, 2.0 以上)の測定を行い, 正常範囲外のもの を血液凝固異常症と診断した。

急性期治療としては初発例では全例に抗凝固 療法を行い,さらに 258 例中 246 例に線溶療法 を併用した。重症例 12 例には血栓摘除術を行 つた後に線溶療法を行った。また再発例につい ては 12 例とも抗凝固療法および線溶療法を行 った。抗凝固療法としてはへパリンを治療初日 より $500 〜 1,000 \mathrm{mg} /$ 日を 5 ～7 日間投与し，同 時にワーファリンの投与を開始した。線溶療法
としてはウロキナーゼを初回 48～96 万単位/日 投与し, 以後漸減し 5〜7 日で中止した. 慢性期 では全例にワーファリン投与を行った（平均投 与期間 25 カ月)。ワーファリンコントロールは トロンボテスト (TT) を 1〜3 カ月毎に測定し TT が 25〜 40\%前 後（PT-INR で 1.1〜1.3 前 後）になるように調節した。また 127 例 (49\%) には抗血小板剤の併用が行われ，ワーファリン 投与中止後も平均 5 力月間投与されていた（平 均投与期間 30 力月)。抗血小板剂は線溶療法中 止後より開始し, 91 例にパナルジン $300 \mathrm{mg} /$ 日, 32 例にアスピリン $81 \mathrm{mg} /$ 日, 4 例にシロス タゾール $200 \mathrm{mg} /$ 日が投与されていた.

\section{結果}

治療前に血液凝固検査を行い得た 98 例のう ち 8 例 $(8 \%)$ に血液凝固異常症の合併がみられ た。 その内訳は AT-III 欠乏症 3 例，プロテイン $\mathrm{C}$ 欠乏症 3 例, プロテイン $\mathrm{S}$ 欠乏症 1 例, 抗リ ン脂質抗体症候群 1 例であった (Table. 2)。 ま た APCR は 2.4〜3.8（平均 2.8）で，2.0 以下 の症例はなかった。

Table 2 Deep vein thrombosis with thrombophilia

\begin{tabular}{|c|c|c|c|c|c|c|c|}
\hline & Age & Sex & $\begin{array}{l}\text { Region*2 at } \\
\text { first episode }\end{array}$ & $\begin{array}{l}\text { Pulmonary } \\
\text { embolism }\end{array}$ & $\begin{array}{l}\text { Duration of } \\
\text { warfarin } \\
\text { (months) }\end{array}$ & $\begin{array}{l}\text { Time of recurrence } \\
\text { after halting } \\
\text { warfarin(months) }\end{array}$ & $\begin{array}{c}\text { mean T.T. } \\
(\%)\end{array}$ \\
\hline $\begin{array}{l}\text { At-III deficiency } \\
\qquad(45 \%)^{* 1}\end{array}$ & 14 & $\mathrm{M}$ & $\mathrm{R}$ & - & 91 (continued) & - & 32 \\
\hline $\begin{array}{c}\text { Protein C deficiency } \\
(35 \%)\end{array}$ & 51 & $\mathrm{~F}$ & $\mathrm{R}$ & - & 27 (continued) & - & 28 \\
\hline $\begin{array}{l}\text { Antiphospholipid } \\
\text { syndrome }\end{array}$ & 46 & $\mathrm{M}$ & $\mathrm{L}$ & - & 35 (continued) & - & 30 \\
\hline $\begin{array}{l}\text { AT-III deficiency } \\
(57 \%)\end{array}$ & 57 & M & $\mathrm{R}$ & + & 18 (halted) & 1 & 24 \\
\hline $\begin{array}{l}\text { AT-III deficiency } \\
(58 \%)\end{array}$ & 40 & M & $\mathrm{R}$ & - & 20 (halted) & 8 & 27 \\
\hline $\begin{array}{r}\text { Protein C deficiency } \\
(46 \%)\end{array}$ & 20 & M & $\mathrm{L}$ & - & 20 (halted) & 10 & 36 \\
\hline $\begin{array}{r}\text { Protein C deficiency } \\
(45 \%)\end{array}$ & 45 & $\mathrm{~F}$ & $\mathrm{R}$ & + & 10 (halted) & 36 & 32 \\
\hline $\begin{array}{l}\text { Protein S deficiency } \\
(48 \%)\end{array}$ & 38 & $\mathrm{~F}$ & $\mathrm{~L}$ & - & 15 (halted) & 7 & 29 \\
\hline
\end{tabular}

*1 ( ) : AT-III activity, Protein C activity or Protein S activity

${ }^{* 2}$ L : left lower extremity

$\mathrm{R}$ : right lower extremity 
また慢性期に下肢深部静脈血栓症が再発した 症例は 258 例中 12 例（5\%）であったが，この うち血液凝固異常症合併例は 5 例 $(42 \%$ ） と高 率にみられた。再発例における初発時および再 発時の罹患肢は同側 6 例，反対側 6 例であっ た。下肢周径差からみると再発例はいずれも初 発例と比べて特に重症化しておらず，初発時お よび再発時ともへパリンと線溶療法にて軽快し た。

慢性期の薬物療法については，非再発例では ワーファリンは平均 25 カ月間投与されており, 抗血小板剤は平均 30 力月間投与されていた。一 方，再発例ではワーファリンは 12 例中 10 例が 初発時から平均 22 力月間投与され,抗血小板剂 は平均 27 カ月間投与されていた.ワーファリン および抗血小板剤の投与期間に関しては再発例 と非再発例で有意差はなかった。また再発例の うちの残り 2 例は発症 1 年以内でワーファリン と抗血小板剤の投与中に再発したが，TT が 15～100\%と変動が激しくワーファリンコント ロール不良時期に再発していた。この 2 例を除 いた 10 例の再発時期はワーファリン投与中止 後 1 カ月から 36 カ月の間であった。この 10 例
の再発例中 2 例は抗血小板剤単独投与中の再発 であり，2 例とも血液凝固異常症を合併してい た。結果的に抗血小板剤投与中に再発した症例 はワーファリンコントロール不良中に再発した 2 例を含めると全 12 例中 4 例であった（Table. 3).

また，246 例の非再発例には 3 例の血液凝固 異常症合併例が含まれているが，いずれも現在 までワーファリン投与を継続中であ,る。また， 再発例でも再発後は現在までワーファリンを投 与し，再発をみていない。

肺塞栓症に関しては初発時に胸痛，血痰ある いは呼吸困難などの自覚症状がみられた症例は 258 例中 4 例であり，また肺シンチグラフィー にて血流異常が確認された症例は 107 例中 36 例であった。このうち慢性期に再発がみられた 症例で初発時に自覚症状のみられた症例はな く, 肺シンチグラフィー陽性例も 9 例中 1 例も なかった。再発時に自覚症状がみられた症例は 12 例中 1 例で，シンチグラフィー陽性例は 12 例中 3 例であった。陽性例はいずれもワーファ リンや抗血小板剤の投与はされていなかった。 血液凝固異常症合併の有無による発生率の差は

Table 3 Recurrence of deep vein thrombosis

\begin{tabular}{|c|c|c|c|c|c|c|}
\hline $\begin{array}{l}\text { Region }{ }^{* 1} \text { at } \\
\text { first episode }\end{array}$ & $\begin{array}{l}\text { Region*1 at } \\
\text { recurrence }\end{array}$ & $\begin{array}{l}\text { Duration of } \\
\text { Warfarin } \\
\text { (months) }\end{array}$ & $\begin{array}{l}\text { Time of recurrence } \\
\text { after halting warfarin } \\
\text { (months) }\end{array}$ & Thrombophilia & $\begin{array}{c}\text { mean TT } \\
(\%)\end{array}$ & $\begin{array}{l}\text { Antiplatelet } \\
\text { drug } \\
\text { at recurrence }\end{array}$ \\
\hline $\mathrm{R}$ & $\mathrm{R}$ & 18 (halted) & 1 & AT-III deficiency & $24 \pm 5$ & $A^{* 3}$ \\
\hline $\mathrm{R}$ & $\mathrm{L}$ & 20 (halted) & 8 & AT-III deficiency & $27 \pm 8$ & $\mathrm{P}^{* 3}$ \\
\hline $\mathrm{L}$ & $\mathrm{L}$ & 20 (halted) & 10 & Protein C deficiency & $36 \pm 7$ & - \\
\hline $\mathrm{R}$ & $\mathrm{L}$ & 10 (halted) & 36 & Protein C deficiency & $32 \pm 9$ & - \\
\hline $\mathrm{L}$ & $\mathrm{L}$ & 15 (halted) & 7 & Protein S deficiency & $29 \pm 4$ & - \\
\hline $\mathrm{L}$ & $\mathrm{R}$ & 22 (halted) & 36 & - & $30 \pm 10$ & - \\
\hline $\mathrm{L}$ & $\mathrm{R}$ & 26 (halted) & 20 & - & $29 \pm 5$ & - \\
\hline $\mathrm{L}$ & $\mathrm{R}$ & 22 (halted) & 28 & - & $29 \pm 6$ & - \\
\hline $\mathrm{L}$ & $\mathrm{L}$ & 38 (halted) & 22 & - & $33 \pm 7$ & - \\
\hline $\mathrm{L}$ & $\mathrm{R}$ & 29 (halted) & 12 & - & $31 \pm 6$ & - \\
\hline $\mathrm{L}$ & $\mathrm{L}$ & 78 (continued) & $(11)^{* 2}$ & - & $35 \pm 21$ & $A^{* 3}$ \\
\hline $\mathrm{L}$ & $\mathrm{L}$ & 61 (continued) & $(8)^{* 2}$ & - & $40 \pm 31$ & $\mathrm{P}^{* 3}$ \\
\hline
\end{tabular}

${ }^{* 1} \mathrm{~L}$ : left lower extremity

$\mathrm{R}$ : right lower extremity

${ }^{* 2}$ period from first episode

${ }^{* 3} \mathrm{~A}$ : Aspirin $81 \mathrm{mg} /$ day

$\mathrm{P}$ : panaldin $300 \mathrm{mg} /$ day

- : none 
Table 4 Pulmonary embolism

\begin{tabular}{lccc}
\hline & First episode & (recurrent case) & recurrence \\
\hline clinical symptoms & $4 / 258(2 \%)$ & $(0 / 12)$ & $1 / 12(8 \%)$ \\
Pulmonary scintigraphy & $36 / 107(34 \%)$ & $(0 / 9)$ & $3 / 12(25 \%)$ \\
IVC filter & 8 & $(0)$ & 1 \\
\hline
\end{tabular}

無かった（Table. 4).

また急性期の線溶療法や慢性期のワーファリ ンおよび抗血小板剤の投与に関連すると思われ る重篤な出血性合併症はみられなかった。

\section{考 察}

本邦では下肢深部静脈血栓症の発生頻度は欧 米と比較して低く，これに併発する肺塞栓症も 少ないとされてきた。また深部静脈血栓症は合 併症としての肺塞栓症さえ回避できれば生命予 後に関しては良好な疾患である。それゆえか本 邦では本疾患の発生率や再発率などの疫学, 慢 性期における薬物治療などに関してはほとんど 検討されてこなかった．深部静脈血栓症の発生 率に関する報告は少ないが，欧米では人口 100 万人あたり 400 例前後との報告があり ${ }^{1)}$ ，本邦 では上林 ${ }^{2)}$ が 100 万人あたり 42 症例と推定し ており,欧米との発生率の差は 10 倍近くになる と推測される。一方，再発率に関してはほとん ど報告がみられず，本邦における報告はわれわ れが調べ得た限り見当たらなかった。また欧米 の報告も少なく ${ }^{344)}$, Acheson らによると深部静 脈血栓症にて退院後 14 週以降では抗凝固療法 の有無にかかわらず再発率に差はなく約 10 人/ 1,000 ・患者・月であるとされている. 今回，わ れわれの検討では平均 34 力月間の観察で約 $5 \%$ 再発がみられたが，ほかの報告と比較検 討できずこの再発率が妥当な数字であるかどう かは不明であり，また再発率を低下させるため に長期間抗凝固療法を継続することが望ましい のかどうかも検討できなかった。

血液凝固異常の発生率について, 欧米におい てはアンチトロンビン III 欠乏症が人ロ 250 人 に 1 人5), プロテインC 欠乏症が $200 〜 300$ 人に

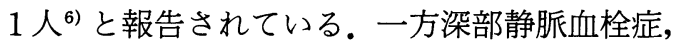
肺血栓症, 動脈血栓症, 脳血栓症など血栓性疾 患に合併した血液凝固異常症の頻度は 5〜 50\% と言われている7). 特に欧米では若年者の閉塞 性動脈硬化症の $90 \%$ 前後に何らかの血液凝固 異常症がみられている ${ }^{8)}$. また, 深部静脈血栓症 では APCR の頻度が 20〜 $00 \%$ にもぶとの報 告もあり ${ }^{9)}$, 血栓性疾患では血液凝固異常症の 関与が重要視されている。今回の検討では約 $8 \%$ に血液凝固異常症の合併が見られ，すでに本 邦では深部静脈血栓症の血液凝固異常症の合併 率は約 $3 \%$ との報告もある ${ }^{10)}$ が，いづれの合併 率も欧米の報告よりもはるかに少なく，特に APCR に関しては今回の検討では 1 例もなか った。また血液凝固六進に関しては以前より血 清脂質，特にコレステロールと血液凝固第VII因 子との関連性が注目されており ${ }^{11)}$ ，深部静脈血 栓症でも高コレステロール血症の関与を指摘す る報告がみられる ${ }^{12)}$ ：これら血液凝固異常症の 合併頻度や高コレステロール血症の頻度などの 差が本邦と欧米との発生率の差の一因をなすも のと考えられる。また再発率に関しては詳細は 不明であり，さらに血液凝固異常症を合併して いる症例の再発率に関しても不明である。しか し, 今回の検討では再発症例のうち約 $40 \%$ に血 液凝固異常症を合併しており，血液凝固異常症 を合併している症例の再発率は高率と推測され る.

下肢深部静脈血栓症の治療に関しては急性期 においてはへパリンによる抗凝固療法とともに 線溶療法あるいは外科手術を行い，慢性期にお いてはワーファリンによる抗凝固療法を行うこ とはほほ確立された治療法である ${ }^{13) 14)}$ 。本邦に おける星野らによるアンケート調査 ${ }^{15)}$ からみ ると，急性期治療は外科手術より線溶療法を行 
っている施設が多い.しかし，慢性期における ワーファリン継続期間に関しては 6 カ月から 1 年以上と施設により異なり，ワーファリンの継 続期間に関しては明確な基準は確立されていな い. Acheson ら ${ }^{3)}$ の報告によれば 14 週以降は ワーファリン投与例と非投与例の再発率に有意 差はなく，4 力月程度の投与で十分と思われる が, 本邦では 1〜2 年間投与することが多いよう である ${ }^{15)}$.また最近，抗血小板剤の投与が深部 静脈血栓症あるいは肺塞栓症の予防に有効であ るとの報告がみられた ${ }^{16)}$ が，ワーファリンと比 較した場合の有効性に関しては不明である。し かし，ワーファリン投与中の凝固能モニタリン グの煩雑さを考えると臨床的には用いやすいと 考えられる. 確かに今回の検討では発症後 1 年 以上経過した血液凝固異常症を合併していない 症例では抗血小板剤内服中に再発がみられた症 例はなく，その限りでは有効性は示唆された。 しかし血液凝固異常症を合併している症例では 抗血小板剤単独投与中に再発した症例が 2 例あ $\eta$ ，血液凝固異常症合併例に対する抗血小板剤 単独の再発予防効果には限界があるものと考え られる。一方，血液凝固異常症合併例でもワー ファリンを投与し凝固能を良好にコントロール していれば再発はみられず，血液凝固異常症合 併例ではワーファリンの長期投与，できれば終 生にわたる投与が必要であると推測される。た だしワーファリンのコントロールレベルに関し ては結論が得られておらず，ほかの血栓性疾患 と同様に本邦では欧米に比べ緩やかであること が多いようである1517)．われわれの施設では一 般的には TTで $25 \sim 40 \%$ 前後を目標にし, 約半 数の症例に抗血小板剂を併用し今回のような結 果を得た。この結果が妥当な成績かどうかにつ いては他に類似の報告が見当たらず，比較検討 できなかった。しかし，再発に関して言えば満 足できる成績であったと考えられる。しかし， 深部静脈血栓症では再発以外にも肺塞栓の予 防，遠隔期における自覚症状の改善あるいは深 部静脈血栓症そのものの発生予防など解決すべ
き問題も多く，今後さらに検討を必要とするも のである。

今回，血液凝固異常症を合併した深部静脈血 栓症について臨床的に検討してきたが，結論と しては再発例では高率に血液凝固異常症を合併 しており，再発に関しても血液凝固異常症の関 与が大きいものと思われた。また再発時期はワ ーファリン投与中止後，あるいはコントロール 不良時期であり，逆に血液凝固異常症合併例で も抗凝固療法を継続している症例には再発はな く，抗凝固療法は再発予防には有効であると思 われた。特に血液凝固異常症合併例では生涯に わたる抗凝固療法が必要であると考えられる。

\section{文 献}

1) Anderson FA, Wheeler HB, Goldberg RJ, : A population based perspective of the incidence and case-fatality rate of venous thrombosis and plumonary embolism; The Worcester DVT study. Arch Intern Med 151 : 933-970, 1991.

2）上林純一: 本邦専門施設における深部静脈血栓症お よび肺塞栓症診療の現状, 斎藤英彦 編, 厚生省特定 疾患 血液凝固異常症調査研究班 平成 7 年度研究 報告書. 東京, 1996, 55-58.

3) Acheson L, Speizer FE, Tager I : Venous thrombosis : Duration of anticoagulant therapy. N Engl J Med 193 : 879-879, 1975.

4) Schulman S : A comparison of six weeks with six months of oral anticoagulant therapy after a first episode of venous thromboembolism. N Engl J Med 332 : 1661-1665, 1995.

5) Tait RC, Walker ID, Perry DJ, Carrell RW, Islan SIA, Call FMc, Mitctell R, Davidson JF : Prevalence of antithrombin III deficiency subtypes in 4000 healthy blood donors. Thromb Haemost 65 : 839-839, 1991.

6) Miletich J, Sherman L, Broze G Jr: Absence of Thrombosis in subjects with heterozygous protein C deficiency. N Engl J Med 317:991-996, 1987.

7）高松純樹, 利見和夫, 松下正, 濱口元洋 : 先天性血栓 
傾向. Medicina $26: 2358-2360,1989$.

8) Levy PJ, Gonzalez MF, Hornung CA, Chang WW, Haynes JL, Rush DS : A prospective evaluation of atherosclerotic risk factors and hypercoagulability in young adults with premature lower extremity atherosclerosis. J Vasc Surg 23 : 36-45, 1996.

9) Koster T, Rosendaal F, De Ronde H, Briët E, Vandenbroucke JP, Bertina RM : Venous thrombosis due to poor anticoagulant response to activated protein $\mathrm{C}$ : Leisen thrombophilia study. Lancet 342 : 1503-1506, 1993.

10）古川欽一: 静脈疾患における血液学的アプローチ小 委員会報告, 三島好雄 編, 厚生省 特定疾患系統的 脈管障害調查研究班 1989 年度研究報告書. 東京, 厚 生省保健医療局疾病対策課, 1990, 19-20.

11) Balleisen L, Assman G, Bailey J, Epping PH, Schulte $\mathrm{H}$, van de Loo J : Epidemiological study on factor VII, factor VIII and fibrinogen in an industrial population-II. Baseline data on the relation to blood pressure, blood glucose, uric acid and lipid fractions. Thromb Haemost 54 :
721-723, 1985.

12）川崎富夫, 上林純一, 有吉秀男, 門田守人 : 危険因子 解析に基づく下肢深部静脈血栓症の治療. 日血外会 誌 5 : 131-135, 1996.

13）石丸 新: 深部静脈血栓症. 臨床外科 49:681-686, 1994.

14）石丸 新, 長田鉄也, 箱島 明, 平山哲三, 山口 寛, 古川欽一 : 深部静脈血栓症に対する血栓摘除術の遠 隔成績一術後積極的補助療法の効果を中止に一. 脈 管学 29 : 1263-1267, 1989.

15）星野俊一, 佐戸川弘之 : 深部静脈血栓症. 本邦におけ る静脈疾患に関する Survey I. 静脈学 8:307-311, 1997.

16) Antiplatet Trialist's Collaboration : Collaborative overview of randomized trials of antiplatelet therapy. BMJ $308: 235-246,1994$.

17) Poller L : Oral anticoagulants and heparin : standardization of laboratory monitoring, in Poller L, Thomson JM (eds) : In Thrombosis and its Management, Churchill Livingstone, Edinburgh, 1993, 200-213.

\title{
Study on Deep Vein Thrombosis with Thrombophilia
}

\author{
Yoshihide YAO*, Shin ISHIMARU* \\ Key words : deep vein thrombosis, reccurent deep vein thrombosis, thrombophilia, \\ warfarin, antiplatelet drug
}

We retrospectively studied the correlative recurrences of deep vein thrombosis (DVT) and thrombophilia in 258 patients with DVT. Subjects were followed for 4 to 115 months (mean 34 months). Recurrences were seen in 12 of 258 patients. The presence of thrombophilia in DVT was observed in 8 of 98 patients ( 3 with antithrombin III deficiency, 3 with protein $\mathrm{C}$ deficiency, 1 with protein $\mathrm{S}$ deficiency, 1 with antiphospholipid syndrome), and recurrent DVT with thrombophilia was seen in 5 of 12 patients with recurrent DVT. Recurrence of DVT occured from 1 to 36 months after halting warfarin therapy. In conclusion, long term warfarin therapy is necessary for the prevention of recurrent DVT with thrombophilia. 